\title{
Comparative Study on the Rate of Flammability of Biogas and Firewood
}

\author{
Saddam Saleh Yusuf, Muhammad Ismail, Jibrin Abdullahi \\ Department of Geography and Environmental Management, Faculty of Physical Science, Ahmadu Bello University, Zaria, Nigeria \\ Email address: \\ saddamyusuf@gmail.com(S. S. Yusuf) \\ To cite this article: \\ Saddam Saleh Yusuf, Muhammad Ismail, Jibrin Abdullahi. Comparative Study on the Rate of Flammability of Biogas and Firewood. \\ American Journal of Energy Engineering. Vol. 8, No. 3, 2020, pp. 26-33. doi: 10.11648/j.ajee.20200803.11
}

Received: August 13, 2020; Accepted: August 26, 2020; Published: September 10, 2020

\begin{abstract}
The increasing negative effects of hydro carbon fossil fuels on the environment has called for quest for alternative source of energy. Among the renewable energy sources, biogas has been evaluated as one of the most effective, efficient and environmentally benign sources of energy. This study evaluates the flammability of biogas produced from cow dung compared with firewood. The experiment was conducted batch wise in mixing ratio 1:1 at mesophilic temperature under 25 days retention time. Weighing balance was used to measure the cow dung and firewood. Biogas production and firewood flammability were measured using combustibility test in seconds using stopwatch. The total gas yield was burnt and recorded 5,088 seconds (1hour $24.8 \mathrm{mins}$ ), on average $1 \mathrm{~kg}$ of cow dung produces biogas that burns for 636 seconds (10.6mins), the gas burnt with clear blue flame revealing the effectiveness of water scrubbing method, while the $8 \mathrm{~kg}$ of firewood was burnt 8,208 seconds (2hours $28 \mathrm{mins}$ ). On average $1 \mathrm{~kg}$ of wood fuel burns for 1,026 seconds $(17.1 \mathrm{mins})$. Comparing the result in term of flammability and efficiency, Biogas could be used as waste management option, generate light and run vehicles and at the same time replace the use of firewood which produces toxic gases that are harmful to health, thus biogas is more efficient.
\end{abstract}

Keywords: Biogas, Firewood, Combustibility Test, Waste Management

\section{Introduction}

Energy crisis and climate change are major issues of concern globally. It is predicted that there will be severe energy shortage in the coming 50 years. According to researches prediction, the crude oil will run out within 40 to 70 years, and natural gas will be finished within 50 years [8]. In relation to this, global average temperature is predicted to increase by $1.8-6.4^{\circ} \mathrm{C}$ by year 2100 and continue to rise long after that $[10,7,13]$. It is also noted that, the world population is predicted to reach 8.6 billion in 2030, 9.8 billion in 2050 and 11.2 billion in 2100 [27, 2], which must be provided with energy and materials for survival [25].

Africa is a net energy exporter, but the majority of its population lacks access to modern fuels, and many countries rely on imported energy [3]. Many people [more than 600 million people in Africa] in developing countries do not have access to advanced forms of energy such as electricity $[6,26]$. And as a result of this they rely on solid forms of biomass [firewood, agricultural residues, animal wastes, etc.] and fossil fuels [kerosene and natural gas] to meet their basic energy needs for cooking and lighting $[6,26]$. At the same time, over $60 \%$ of the total wood in developing countries has been used as wood fuel. This has resulted in depleting of forests resources at a more rapid manner than they can be replaced [25]. However, the disadvantages of these traditional fuels are many. First, they are inefficient energy carriers and their heat is difficult to control, also they produce dangerous emissions and their current rate of extraction is not sustainable [3].

Another burning problem currently facing the world is the management of all types of wastes and energy. This is attested by $[15,31]$ that rapid growth of population, uncontrolled urbanization has created serious problems of energy requirement and solid waste disposal. It is becoming growing problem for national and local governments to ensure effective and sustainable management of waste [30]. As population number increases, waste management and provision of sustainable energy for economic development become challenging. Waste generation in Nigeria is estimated at $0.65-0.95 \mathrm{~kg} / \mathrm{capita} /$ day which gives an average of 42 
million tonnes of the total 62 million tonnes of wastes generated in sub-Saharan Africa annually and the issue of where and how to channel these wastes become a huge problem for the nation [12].

However, the issue of climate change mitigation is a critical challenge that needs to be tackled. One of the ways to reduce pollution and mitigate climate change as well as maintain healthy environment is to convert organic wastes into energy in form of biogas. According to [15] and [28] the production of methane-rich biogas through anaerobic digestion of organic materials provides a versatile carrier of renewable energy, as methane can be used in replacement of fossil fuel in both heat and power generation as well as vehicle fuel. Thus, this eventually reduces the emissions of greenhouse gases and slows down the climate change. Methane production through anaerobic digestion has been evaluated as one of the most energy-efficient and environmentally benign ways of producing vehicle bio-fuel. In attestation to this, [5], [21] affirms that anaerobic digestion (AD) is an effective, low-cost approach that offers many environmental benefits, such as generation of renewable energy [methane and hydrogen], production of soil amendments, alcohol, volatile fatty acids (VFAs), and other valuable materials, and reduction of greenhouse gases $\mathrm{GHG}$ ).

In this study, a local digester and biogas burner were fabricated and a batch trial was conducted to determine the biogas production using the fabricated digester. The Anaerobic digestion was conducted under mesophilic temperature range. Combustibility tests were carried out to compare the flammability rate of the biogas and the firewood.

\section{Materials and Method}

As a general rule, the selection of all the materials used for the fabrication of digester was based on cost-effectiveness, availability and durability [14]. The materials for this study include; 25 -liter plastic galloon, $1 / 2$ inch hose, $1 / 2 \mathrm{~T}$ junction, $1 / 2$ elbow, $1 / 2$ male and female socket, glue (Abro PVC), trade tape, $1 / 2$ Get valve [Air valve], tube water jacket, and fire wood as shown in Figure 1 and 2

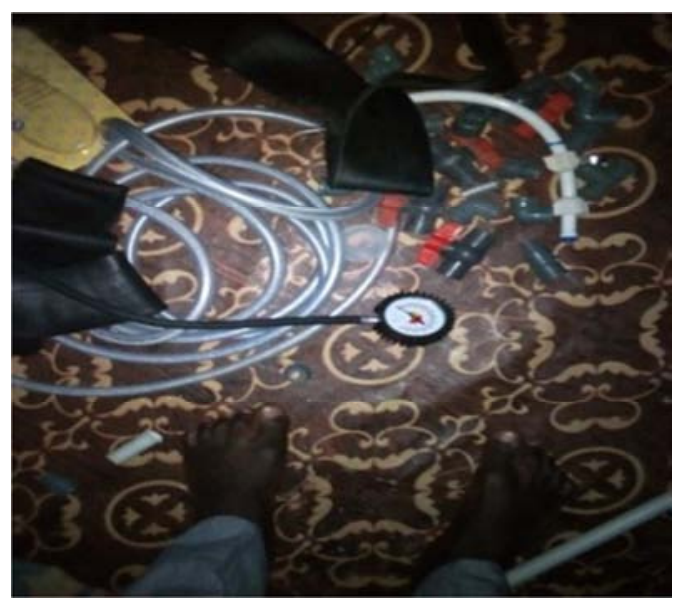

Figure 1. Materials.

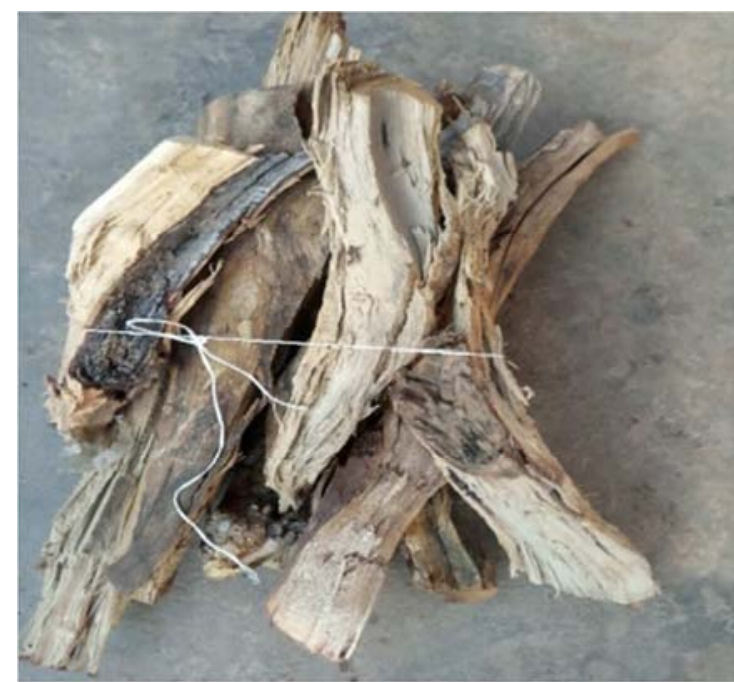

Figure 2. Firewood.

\subsection{Digester Design}

The design was made to satisfy the biogas plant essential components as outlined by [14], which are: Digestion chamber which needs to be airtight, Inlet [a medium to feed organic matter into the digestion chamber] and an outlet.

A 25 litre plastic gallon was used as anaerobic digester, 18.9-liter plastic rubber was used as water container via which gas passes for purification. A motorcycle tube was used as gas collection chamber. It was designed to operate at a mesophilic temperature range. The digester was structured to have one opening serving two purposes; slurry inlet and as gas outlet. Half $1 / 2$ inch hose was used for gas transportation to the water container and to the gas collection chamber. Glue (Abro PVC) was used to support the various joints made between the digester, hose, TJunction and the gas collection chamber. Get valve (air valve) was used to control the flow of the gas to the gas collection chamber and the opening to the burner attached as shown in Figure 3.

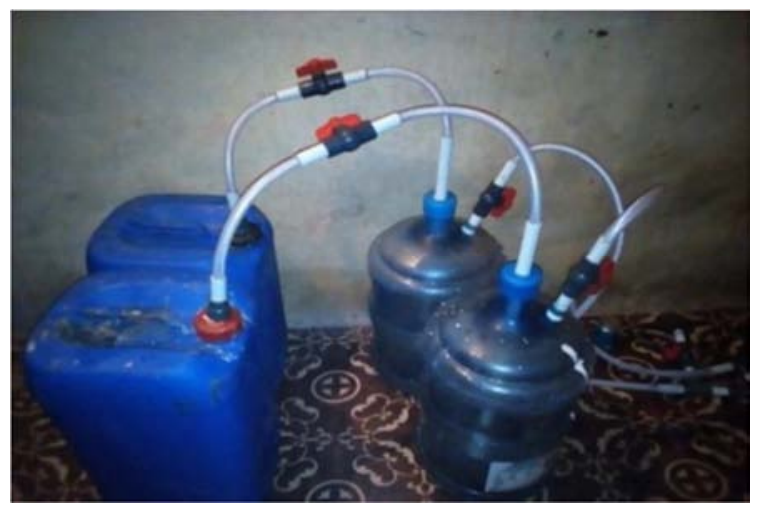

Figure 3. Biogas Digestion plant.

\subsection{Burner Design}

A recycled burner was used; metal flat bar 2 by 2 (two 10 inch and two 11 inches) were used. A pipe of not more than 8 inch and nut of 22 in size were soldered together. The 
burner was attached with the joint pipe and nut. A hole was made in the middle of the two-metal flat bar. The burner was then incorporated in the middle of the hole and was bonded. Two other metal flat bar of 11 inches were joined at the edge of the other two metal flat bars of 10 inches and were bonded as illustrated in figure 4 .

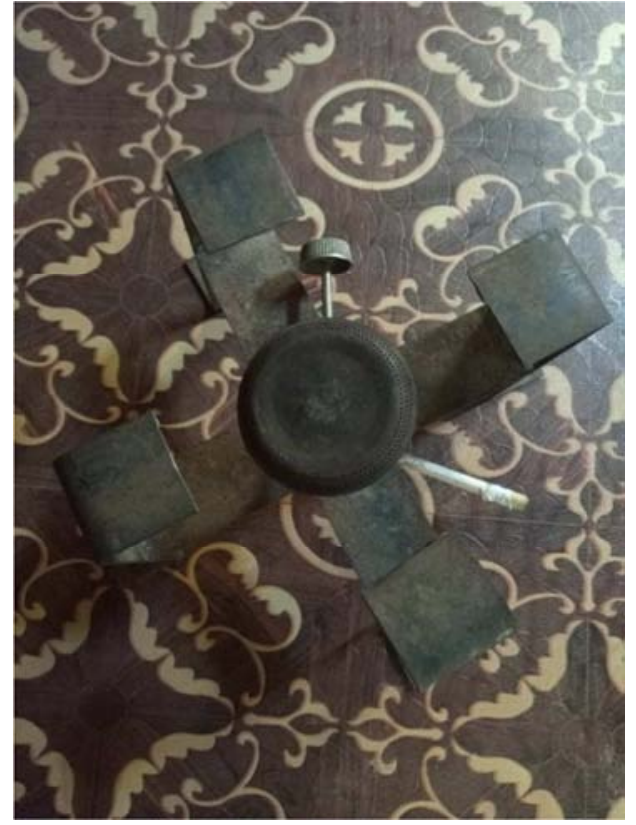

Figure 4. Fabricated Burner.

\subsection{Sample Collection and Preparation}

$8 \mathrm{~kg}$ of fresh Cow dung was collected from Funtua abattoir in covered bucked and was transported to the site, while wood fuel was purchased from Unguwar Musa ward and transported to the site also. $8 \mathrm{Kg}$ of fresh Cow dung was diluted with 8litres of water respectively in ratio $1: 1$ and then fed into the fabricated digester labeled cow dung using funnel (CD) as conducted by [9]. The final mixing of the cow dung and water formed slurry [figure 5]. $8 \mathrm{~kg}$ of wood fuel was measured as shown in figure 6 and then used in conducting combustibility test.

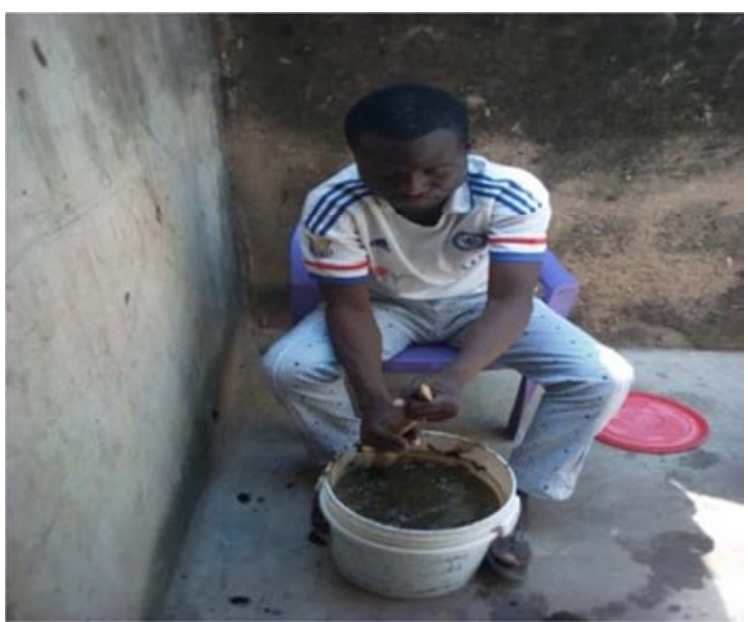

Figure 5. Showing Slurry Preparation.

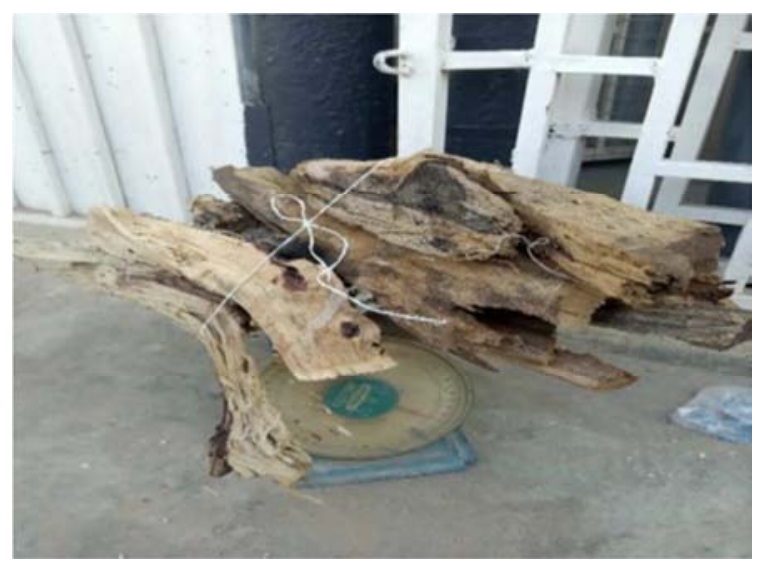

Figure 6. Showing $8 K g$ of wood fuel purchased at the cost of N150.

Temperature: Temperature was recorded to determine the influence of temperature on the digester. $2 / 1^{\circ} \mathrm{C}$ Thermometers was used to measure the ambient temperature in the study area. The ambient temperatures were recorded three times daily; $10 \mathrm{am}, 2 \mathrm{pm}$ and $6 \mathrm{pm}$ respectively as done by [19].

Gas purification: One of the recommended options for removal of Carbon dioxide and hydrogen sulfide is via water scrubbing as recommended by [17] The raw biogas was passed through a water scrubbing unit, since $\mathrm{CO}_{2}$ and $\mathrm{H}_{2} \mathrm{~S}$ have higher solubility than methane $\left(\mathrm{CH}_{4}\right)$, the methane which is 20 times lighter than air was then passed via the water scrubbing unit leaving the higher solubility gases dissolved in the water.

The water scrubber consists of an inlet for the raw biogas to enter into the water and another single outlet for the passage of the Methane $\left(\mathrm{CH}_{4}\right)$ to the collection chamber.

Gas measurement: The gas was measured by conducting flammability test as carried by [4]. The gas produced was collected in the gas collection chamber, a designed burner was attached to the gas collection chamber, and the get valve was switched on to allow the passage of the gas to the burner, a lighter was ignited. A stopwatch was used to record the duration of the combustion in seconds while burning. This method was choosing because it reveals the actual amount of burnable methane gas produced, while other method may record Carbon dioxide and Hydrogen Sulfide as the gases produced especially during the first production where normally $\mathrm{CO}_{2}$ is produced before the methanogenic activation phase. The batch experiment was considered complete when a clear downward trend in daily biogas capacity produced was observed for 10 days.

\section{Results and Discussion}

\subsection{Gas Production Using Combustibility Test}

Figure 7 reveals the daily production of biogas via combustibility test. The total gas produced lasts for 5,088 sec (84.8 mins) in combustion test. The first combustion test was done on $11^{\text {th }}$ which lasts for $120 \mathrm{secs}$ and drastically increase to 460,500 and 620 secs during the 
$12^{\text {th }}, 13^{\text {th }}$ and $14^{\text {th }}$ days retention time respectively. The maximum gas production was recorded on $15^{\text {th }}$ day retention time with combustion rate of 837 secs, it later retards on $16^{\text {th }}, 17^{\text {th }}$ and $18^{\text {th }}$ with combustion rate of 600 , 490 and 391 secs respectively and drops drastically on the following dates $19^{\text {th }}, 20^{\text {th }}, 21^{\text {st }}, 22^{\text {nd }}$, and $23^{\text {rd }}$ to 370 secs, 355 secs, 129 secs, 119 secs and 97 secs. The process then inhibits with no gas production during the dates that followed.

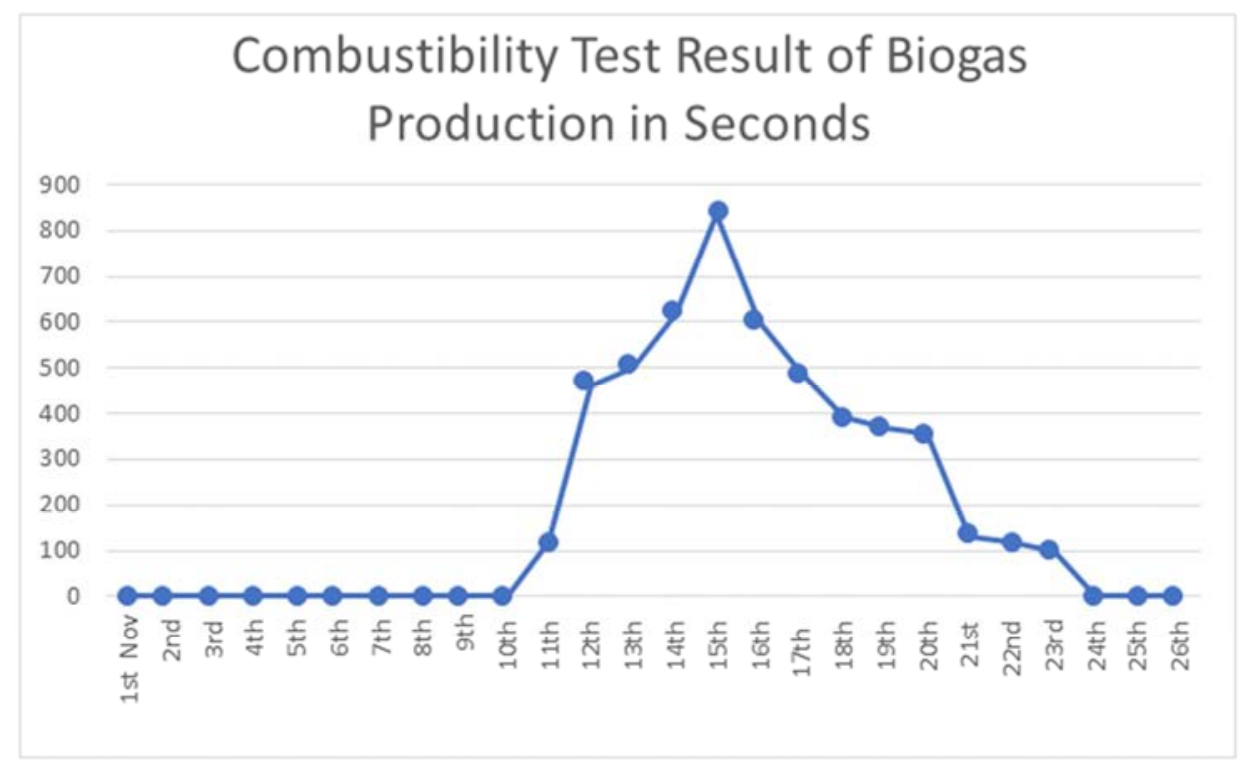

Figure 7. Showing the result of combustibility test.

Gas production starts during the second week of the plant set up; which was an improvement on the findings of [1] who reported production on first, second and third day after pre-fermentation for 15 days, and very close to that of [19] who revealed production during the first week of plant set up, on the $8^{\text {th }}$ day. On $11^{\text {th }}$ day, a burnable gas was produced from the Cow dung with vividly clear blue flame which was characterized with blue, little tinged orange color flame and has no smoke. The little tinged orange flame indicated the presence of Hydrogen sulfide $\left(\mathrm{H}_{2} \mathrm{~S}\right)$.

On $8^{\text {th }}$ to $10^{\text {th }}$ day retention time, the gas produced was colorless and later with some little faint smell like that of rotten egg but was not flammable. The gas extinguished an ignited match, the ability of the gas to extinguish light on ignition indicated the presence of Carbon dioxide $\left(\mathrm{CO}_{2}\right)$ in higher quantity which is inflammable but colorless and odorless as described by [18], [16], [24] while the rotten egg odor indicated the presence of $\mathrm{H}_{2} \mathrm{~S}$ but in low quantity because if it were in higher quantity than $\mathrm{CO}_{2}$ it would be combustible, for combustibility is one of the $\mathrm{H}_{2} \mathrm{~S}$ characteristics as revealed by $[23,20]$. On the $10^{\text {th }}$ day retention time the Carbon dioxide production ceased; this marks the activation phase of methanogenic which produces burnable gas on $11^{\text {th }}$ day of the plant set up.

The gas produced was burnt using the designed burner, it burns with clear blue flame from the $12^{\text {th }}$ day retention time onward. The gas produced was colorless and has no orange flame as shown in figure 8 , this shows $\mathrm{H}_{2} \mathrm{~S}$ was removed. The locally fabricated digester that was designed to digest and produce gas, the biogas burner that was made to burn the produced biogas and the water container that was designed to serve as water scrubber has proved effective by performing the functions. Thus, the gas can be used to run vehicles, heating and cooking. It could also be drawn from this research finding that $1 \mathrm{~kg}$ of cow dung produces biogas that burn for an average of 636 seconds (10.6min approximately $11 \mathrm{mins}$ on average). Moreover, the gas was very easy to ignite, control and produced no smoke.

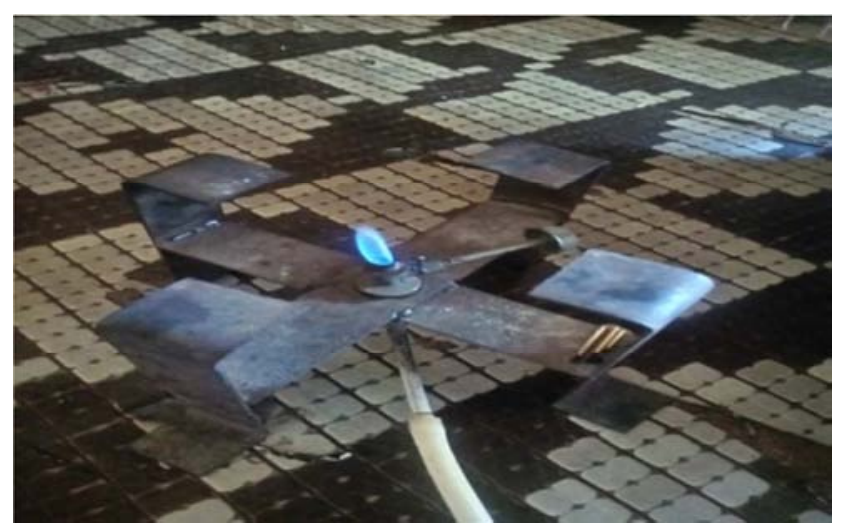

Figure 8. Constructed Burner showing clear blue flame of the biogas produced.

Digestion Temperature: Figure 9 reveals the daily temperature fluctuation. The temperature has been fluctuating within mesophilic range. The highest temperature record was $37^{\circ} \mathrm{C}$ during the first 3 days on $2^{\text {nd }}, 3^{\text {rd }}$ and $4^{\text {th }}$ of the plant set up which was before the gas production starts. The highest methane production was recorded on $15^{\text {th }}$ day when the daily average temperature records was $32^{\circ} \mathrm{C}$ as shown in figure 10. This finding agrees with that of [29] 
who obtains optimum production when the temperature reading was $30^{\circ} \mathrm{C}-30^{\circ} \mathrm{C}$. [4] also asserts that, the temperature range of $30^{\circ} \mathrm{C}-34^{\circ} \mathrm{C}$ is the best for biogas production while [14], [22] reiterated that satisfactory and maximum methane production takes place in the mesophilic range, the optimum temperature being $35^{\circ} \mathrm{C}$. According to this current research, the optimum biogas production occurs when the temperature reading ranges from $30^{\circ} \mathrm{C}-35^{\circ} \mathrm{C}$.

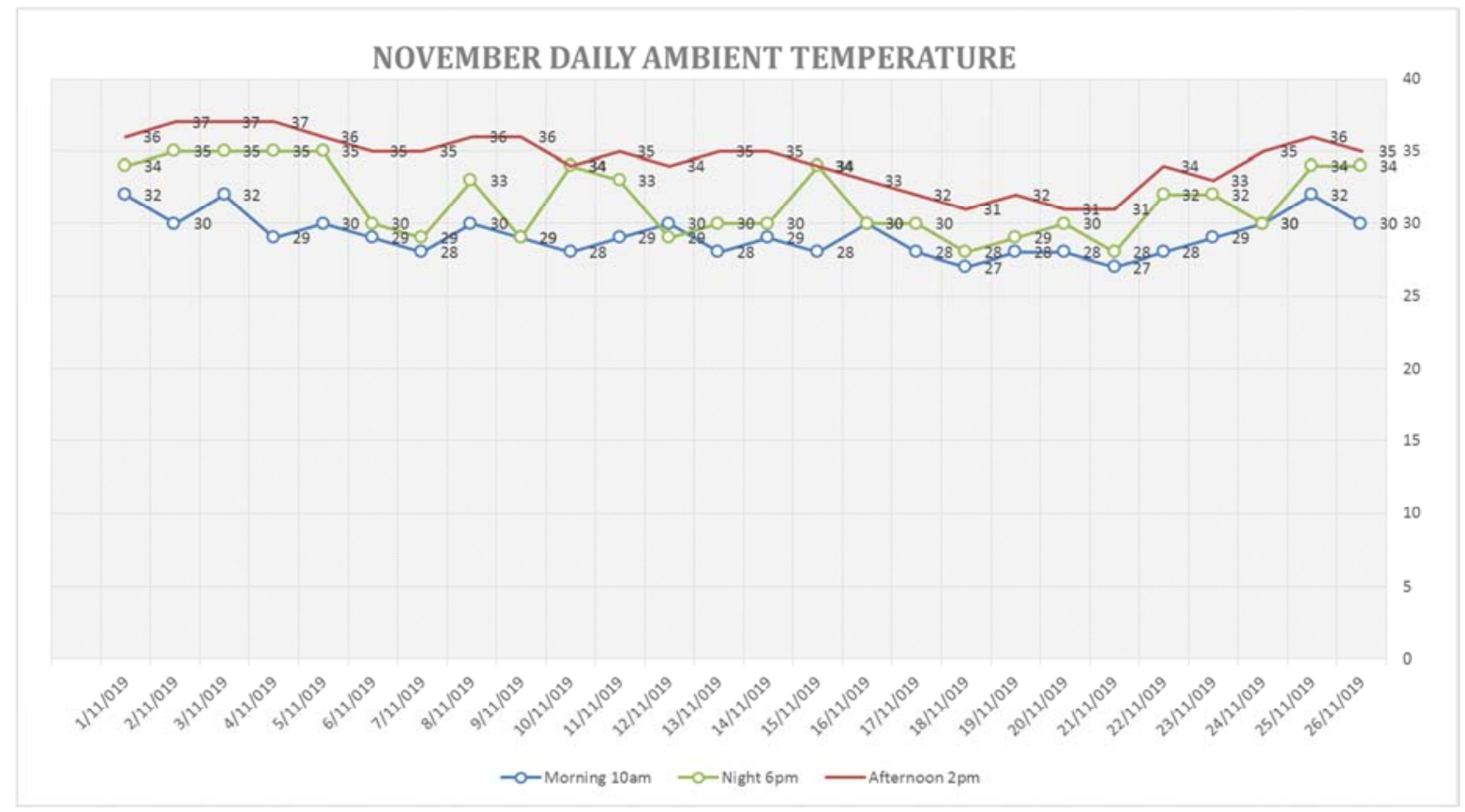

Figure 9. Showing November Daily Ambient Temperature Records.

However, it could be understood from the finding that, the influence of temperature was not subjected to a single day record but sequential constant record of temperature of at least 2 to 3 days. Obtaining maximum or optimum biogas as in the case here was as a result of the constant temperature of $35^{\circ} \mathrm{C}$, $34^{\circ} \mathrm{C}, 35^{\circ} \mathrm{C}$ and $35^{\circ} \mathrm{C}$ on $12^{\text {th }}, 13^{\text {th }}, 14^{\text {th }}$, and $15^{\text {th }}$ on the very day of the highest biogas production. Had it been this trend was maintained for additional two days another optimum production would have been recorded, but the sudden drop in temperature by $-1^{\circ} \mathrm{C},-2^{\circ} \mathrm{C}$ and $-3^{\circ} \mathrm{C}$ affected the subsequent productions as shown in figure 7 and 9., although the effect has not shown on $16^{\text {th }}$ and $17^{\text {th }}$ but on $18^{\text {th }}$ and the subsequent dates.

\section{NOVEMBER DAILY AVERAGE AAMBIENT TEMPERATURE}

40

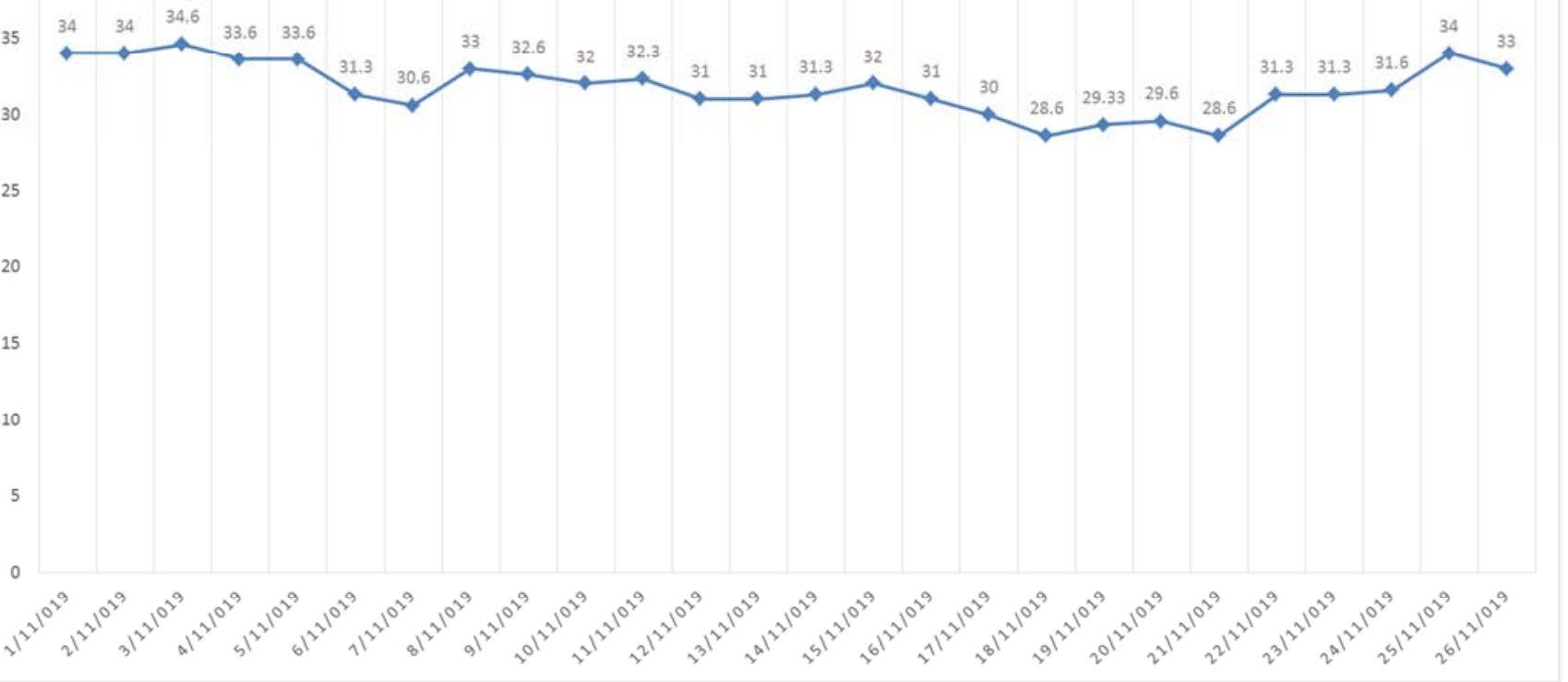

Figure 10. Showing November daily average ambient temperature. 


\subsection{Wood Fuel Combustibility Test}

The test was conducted on $11^{\text {th }}$ of November, 2019 and the wood lasted burning for 8,208 seconds ( 2 hours $28 \mathrm{mins}$ ). On average every $1 \mathrm{~kg}$ of wood fuel burns for 1,026 seconds (17.1 mins). After ignition, the wood took 5 mins giving up smoke and later gave up orange flame. [Figure 11]. In the first 15 mins, the flame was burning slow and later kept burning optimally. The orange flame was accompanied with Ashly colored smoke throughout the burning process as shown in figure 11. The smoke was dangerous to eyes when in contact. The wood was very easy to ignite and has lengthy flame as described by [11], but may be very difficult to control at some certain extent. The product of the wood after burning were Ash and Charcoal as shown in figure 12. The charcoal could be further use for cooking and ironing using local pressing iron but still at the end another ash is produced. It was evident from the research that continuous production of ash from burning of firewood dirt the surrounding and causes eyesore especially when used in open kitchen.

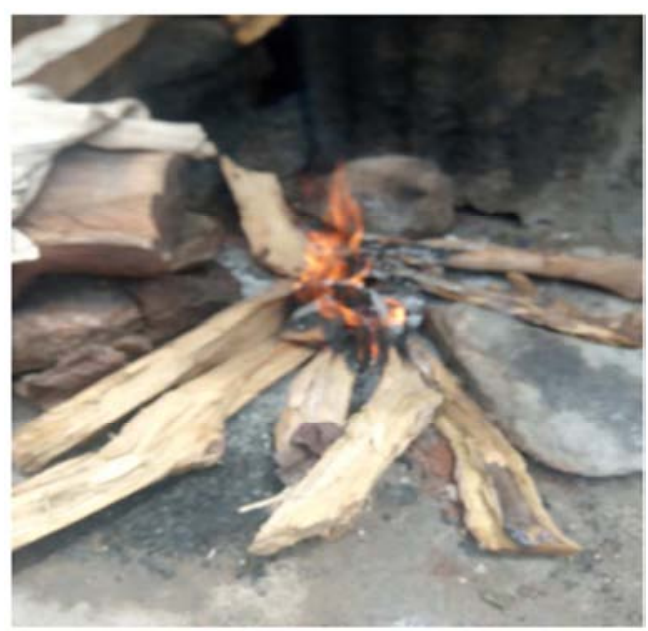

Figure 11. Orange flame from Wood fuel.

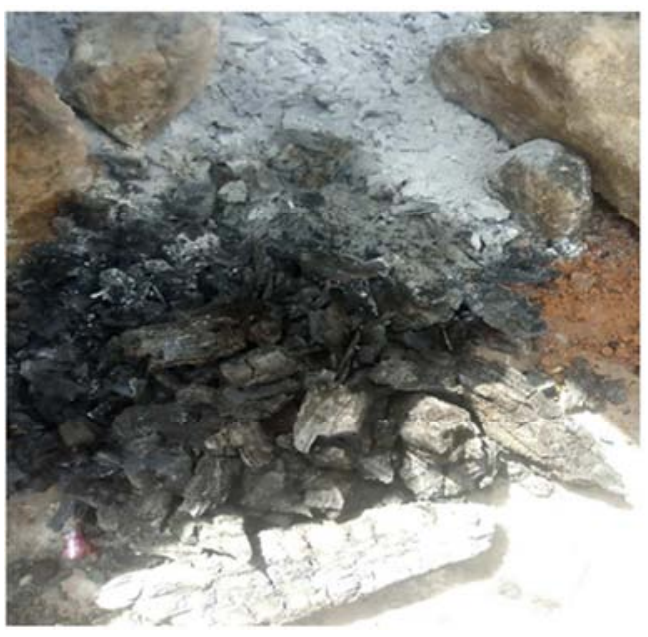

Figure 12. Wood fuel product [Charcoal \& Ash].

From the combustibility test result presented of both biogas and firewood, one may understand why people may go for firewood than biogas, the reason might not be very far away from the lengthy flame that the firewood produced over that of the biogas.

It was evident in some places especially rural areas of Funtua where the study was conducted which has potential for Cow dung production with no proper method of dung disposal which in return pollute the environment; causing eyesore by depleting the aesthetic view of the environment, release of irritating odour and harmful gases. Figure 13 shows the inappropriate disposal on land.

With the efficiency of locally fabricated digester, gas burner and the potential of cow dung in biogas production, this may serve as waste management option with the benefit of replacing firewood in cooking and heating using the biogas produced, thus cutting down the rate of forest depletion by controlling wood fuel consumption. Moreover, wealth may be generated though selling of the dung for biogas generation. A mini scale company for production of biogas may be erected in the area with the aim of upgrading the biogas for running vehicle engines, thus creating job opportunities (wealth from waste) thereby achieving the sustainable development goals number 1 (eradicating poverty), 6 (clean water and sanitation), 7 (affordable and clean energy) and 13 (climate action).

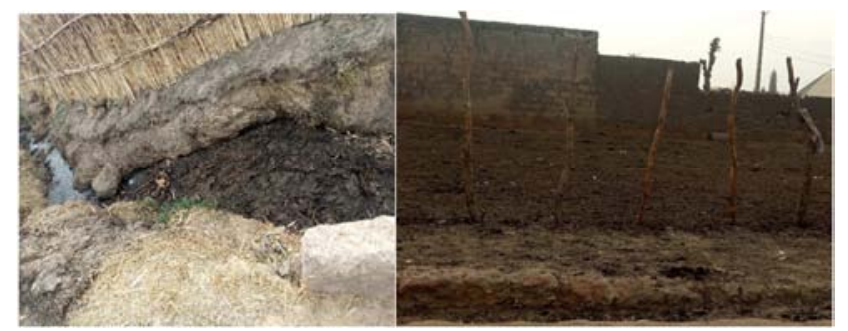

Figure 13. Showing inappropriate cow dung disposal in Sabon Gari and Maigamji ward in Funtua.

\section{Conclusion}

This research has been useful in revealing vital information on the efficiency of locally fabricated anaerobic digestion plant and gas burner to produce burnable gas thus, providing easier method for gas production using locally available materials. The biogas (Methane) could also be used as waste management option and at the same replace the firewood which produces toxic gases that are harmful to health. The research also proves the use of water scrubber to remove Carbon dioxide and Hydrogen Sulfide which upgrades the gas to reach fuel standard or natural gas. At the end of this research and following the outcome of the finding, the research recommends that people should be enlighten on the benefit of using biogas in place of firewood and in the case of using biogas as a vehicle fuel or natural gas, the quality of biogas should be improved by another means suitable other than using water scrubber. The research also recommends an investigative study on peoples' perception on the use of firewood and biogas. 


\section{Author Declaration}

\section{Conflict of Interest}

All the authors do not have any possible conflicts of interest.

\section{Funding}

No funding was received for this work.

\section{Acknowledgements}

The authors appreciate the support of Yaqub Saminu, Abdulmumini Sani, Abdulsalam Salimu, Nazifi Najume, Buhari Magaji, Yusuf Ahmad, Muazzam Ibrahim, Imrana Saidu and Amina Yusuf Saleh for securing the substrates and the site for the conduct of the study and the help of Dr. Buba N. and Bashir, A. Muhammad of Department of Biological sciences, School of Basic and Remedial Studies, Ahmadu Bello University, Zaria, Nigeria for proofreading the work.

\section{References}

[1] Alfa, M. L. [2013]. Comparative Study of Biogas Poduction from Cow Dung, Chicken Droppings and Cymbopogon citratus as Alternative Energy Sources in Nigeria. A MSc Dissertation Submitted to The School of Postgraduate Studies, Ahmadu Bello University Zaria, Nigeria.

[2] Allam Z. [2019]. Enhancing Renewable Energy Adoption in Megacities through Energy Diversification, Land Fragmentation and Fiscal Mechanisms. Sustainable Cities and Society. 1-25. doi: https://doi.org/10.1016/j.scs.2019.101841.

[3] Amigun, B., Parawira W., Musango J. K., Aboyade A. O. and Badmos A. S. [2012]. Anaerobic Biogas Generation for Rural Area Energy Provision in Africa.

[4] Bashir, A. M. [2006]. Construction of suitable digester for biogas production in school laboratories. An unpublished Msc. Thesis submitted to the department of Biological sciences [Education], Ahmadu Bello University, Zaria, Nigeria.

[5] Benyi, X., Wenzhe, Z., Hao, Y., Yu Q., Jing, W., Junxin, L. and Yu-You L, [2018]. Biogas production by two-stage thermophilic anaerobic co-digestion of food waste and paper waste: Effect of paper waste ratio, Renewable energy.

[6] Blimpo, M. P., and Malcolm, C. [2019]. Electricity Access in Sub-Saharan Africa: Uptake, Reliability, and Complementary Factors for Economic Impact. Africa Development Forum series. Washington, DC: World Bank. doi: 10.1596/978-14648-13610. License: Creative Commons Attribution CC BY 3.0 IGO availableat https://openknowledge.worldbank.org/bitstream/handle/1098 6/31333/9781464813610.pdf?seque nce=6\&isAllowed=y.

[7] Chatterjee, D. and Saha, S. [2018] Response of soil properties and soil microbial communities to the projected climate change. In Advances in Crop Environment Interaction [eds Bal, S. et al.] Springer, Singapore. pp. 87-136. 2.

[8] Courtney, B. and Dorman, D. [2003]. World Wide Fossil Fuels. Chemistry Department of Louisiana State University.
[9] Diagi, E. A., Akinyemi, M. L., Emetere, M. E., Ogunrinola, I. E. and Ndubuisi, A. O. [2019]. Comparative Analysis of Biogas Produced from Cow Dung and Poultry Droppings. Earth and Environmental Science. 331 doi: 10.1088/1755$1315 / 331 / 1 / 012064$.

[10] Dow, K., Downing, T. [2006]. The Atlas of Climate Change: Mapping The World's Greatest Challenge. Los Angeles: University of California Press.

[11] Evbuomwan B. O and Okorji C. J [2018]. Determination of The Fuel Wood Properties of Selected Nigerian Wood Trees. Global scientific Journal, vol 6, 7, 1019-1033.

[12] Ike, C. C., Ezeibe C. C., Anijiofor S. C., NikDaud N. N. [2018] Solid waste management in Nigeria: problems, prospects, and policies. The journal of solid waste management, vol. 44.

[13] IPCC, [2014]. Summary for policymakers. In Climate Change: Impacts, Adaptation, and Vulnerability. Part A: Global and Sectoral Aspects. Contribution of Working Group II to the Fifth Assessment Report of the Intergovernmental Panel on Climate Change [eds Field, C. B. et al.], Cambridge University Press, Cambridge, United Kingdom and New York, NY, USA. pp. 1-32.

[14] Karki A., Dhital A., Amrit, M. N., Ram S., Isha K., Pankaj. [eds] [2015]. Biogas as Renewable Source of Energy in Nepal: Theory and Development.

[15] LBS, [2002]. GM Well-to-Wheel analysis of energy use and greenhouse gas emissions of advanced fuel/vehicle systems- $A$ European Study. 133 p., L-B-Systemtechnik GmbH, Ottobrunn Germany.

[16] Li, H., Sun, B., Yuan, Y. and Yang, J. [2019]. Guanidine derivative polymer coated microbubble resonator for high sensitivity detection of $\mathrm{CO}_{2}$ gas concentration. Optic Express, Vol. 27, No. 3. https://doi.org/10.1364/OE.27.001991.

[17] Monnet, F. [2003]. An Introduction to Anaerobic Digestion of Organic Waste. A Report by Remade, Scotland.

[18] Monshi, M. M., Aghaei, S. M and Calizo, I. [2017]. Doping and defect-induced germanene: a superior media for sensing $\mathrm{H}_{2} \mathrm{~S}, \mathrm{SO} 2$, and $\mathrm{CO}_{2}$ gas molecules. Surf. Sci. 665, 96-102.

[19] Musa, R. [2017]. Effects of additives on biogas production from cow dung and chicken dropping mixed with Digitaria smuts ii. A Master's Dissertation Submitted to the Department of Water Resources and Environmental Engineering, Faculty of Engineering Ahmadu Bello University, Zaria Nigeria.

[20] Peng, F., Wang, S., Yu, W., Huang, T., Sun, Y., Cheng, C., Chen, X., Hao, J and Dai1, N. 2020]. Ultrasensitive ppb-level $\mathrm{H}_{2} \mathrm{~S}$ gas sensor at room temperature based on $\mathrm{WO}_{3} / \mathrm{rGO}$ hybrids. Journal of Materials Science: Materials in Electronics. https://doi.org/10.1007/s10854-020-03067-6.

[21] Rajput and Sheikh. [2019]. Effect of inoculum type and organic loading on biogas production of sunflower meal and wheat straw. Sustainable Environment Research. 29: 4.

[22] Ramaraj, R and Unpaprom, Y, [2016]. Effect of temperature on the performance of biogas Production from Duckweed. Chemistry Research Journal, 1 [1]: 58-66.

[23] Ren, B., Zhao, Y., Lyczko, N and Nzihou, A. [2018]. Current Status and Outlook of Odor Removal Technologies in Wastewater Treatment Plant. Waste and Biomass Valorization https://doi.org/10.1007/s12649-018-0384-9. 
[24] Shokravi, M. M and Nasirian, S. [2019]. Improved carbon dioxide gas sensing features of zinc oxide nanorods assisted by an organic fller for dynamic situations. Applied Physics A Material Science and Processing, 125: 730 https://doi.org/10.1007/s00339-019-3021-y.

[25] Sunarso, J., Widiasa S. and Budiyono I. N. [2012]. The Effect of Feed to Inoculums Ratio on Biogas Production Rate from Cattle Manure Using Rumen Fluid as Inoculums. Internat. $J$. of Waste Resources, 2 [1]: 1-4.

[26] UNEP United Nations Environment Programme [2019]. Review of Wood Fuel Biomass Production and Utilization in Africa: A Desk Study.

[27] United Nations. [2017]. World Population Prospects: Key findings \& advance tables. New York, NY: Department of Economic and Social Affairs, Population Division.

[28] Verstraete, W., Morgan-Sagastume, F., Aiyuk, S., Waweru,
M., Rabaey, K., Lissens, G. [2005]. Anaerobic digestion as a core technology in sustainable management of organic matter. Water Science and Technology, 52 [1-2], 59-66.

[29] Wang, Q. Y., Tian, J., Kato, M. T., Rong, Y. J., He, Y. L. and $\mathrm{Ji}, \mathrm{F}$. [2018]. Anaerobic co-digestion of wastes from fruit processing and activated sludge reactor in juice production industry. IOP Conf. Series: Earth and Environmental Science186 [2018] 012042.

[30] Yukalang, N., Clarke. B. and Ross, K. [2017]. Barriers to effective municipal solid waste management in a rapidly urbanizing area in Thailand. Int. J. Environ. Res. Public Health. 14, 1013.

[31] Yukalang, N., Clarke. B. and Ross, K. [2018]. Solid Waste Management Solutions for a Rapidly Urbanization Area in Thailand: Recommendations Based on Stakeholder Input. Int. J. Environ. Res. Public Health. 15, 1302. 